\title{
GENDER ISSUES AND THE SEARCH FOR A HADITH: A JOURNEY IN SCHOLARLY DUE DILIGENCE
}

\author{
Mohammad Omar Farooq*
}

\begin{abstract}
Hadith are the second source of the Islamic way of life in general and of Islamic law and jurisprudence in particular. From a religious perspective, whether in matters of faith or practice, the details of Muslim life are shaped by hadith as the Qur'an, the revealed source of Islam, mostly provides guidance without relevant details. Thus, hadith play a key role in Islamic religious discourse. For this reason, the authentication of hadith has been a pivotal enterprise in Islamic history.

From the earliest period, many hadith appeared that later came to be classified by hadith experts as spurious. One might expect that, by now, Muslims would have become sufficiently circumspect to prevent misattribution of sayings to the Prophet. Indeed, it might be thought that, since all the hadith collections are already in place, there is no room for accretions or distortion of hadith. However, this paper deals with the case of a modern accretion to an otherwise authenticated hadith. While this might not be common, it calls for further circumspection and due diligence by Muslim scholars and other experts.
\end{abstract}

Keywords: Hadith; Hadith verification; Hadith authentication; Sunnah; Gender issues; Last sermon; Sahih; Muhammad; Islam.

\section{Introduction}

Hadith are regarded as the second most important source of guidance in Islam. Though not divine like the Qur'an, hadith provide the details that the Qur'an does not. Much of figh (Islamic law) ${ }^{1}$ is based on hadith. Hadith constituted an oral tradition immediately after the Prophet Muhammad, only being collected in the third century AH into various written compilations, especially the sihah sitta (six authentic collections). ${ }^{2}$ These collections of hadith were based on sifting through hundreds of thousands of hadith to separate the authentic (sahih) from the spurious or fabricated (maudu), while also grading the sahih into sahih, hasan (good), daif (weak) and so on. ${ }^{3}$

The whole intellectual and theological enterprise underlying hadith is vitally important as much of the details of Islam and fiqh depend on hadith. Indeed, Islam 
as we know it is inseparable from hadith. Mainstream Muslims, of course, defer to the due diligence of hadith scholars and researchers. It is important not just for Muslims to have confidence in the guidance of these scholars, but also for nonMuslims, whose scrutiny of Islam and Muslims invariably involves the corpus of hadith. Thus, it is unthinkable that even in our modern times possible accretions or distortions of hadith could occur, especially in the case of already authenticated hadith, due to a lack of proper and adequate due diligence on the part of Muslim scholars and researchers.

This paper thoroughly investigates the origin of a modern accretion to a saying of the Prophet Muhammad, investigating a chain of references available in both academic and non-academic works. The purpose of this paper is to create awareness about a particular instance of distortion that seems to have emerged from a lack of due diligence, indicating that further circumspection is needed in regard to preserving the integrity of the corpus of hadith.

\section{The Background}

Recently, during research collaboration related to women's empowerment in Islam, the current author encountered a variant version of a well-known hadith usually cited in the context of the Prophet Muhammad's sermon during his last hajj (pilgrimage). ${ }^{4}$

The commonly known version reports:

O mankind! Your Lord (Rabb) is one, your parents (Adam/Eve) are one; there is no superiority of an Arab over a non-Arab, or of a non-Arab over an Arab, and no superiority of a white over a black or of a black over a white, except on the basis of God-consciousness (taqwa). ${ }^{5}$

While classifying hadith based on their authenticity is always an issue, ${ }^{6}$ for the purpose of this paper the focus is simply on identifying a variation of this specific text. This particular hadith affirms the egalitarian views and values of Islam in conformity with the Qur' anic perspective:

O mankind, indeed We have created you from a male and a female and made you peoples and tribes that you may know one another. Indeed, the most noble of you in the sight of God is the most righteous/Godconscious (atqakum). Of course, God is Knowing and Acquainted. [Q. 49:13]

A variant version of the above hadith that deserves our special attention, however, is as follows: 
All people are equal, as equal as the tooth of a comb. There is no claim of merit of an Arab over a non-Arab, or a white over a black person, or a male over a female. Only God-fearing people merit a preference with God. $^{7}$

The specific mention of "or a male over a female" is significant because it explicitly addresses and demolishes any notion of superiority in the context of gender. The first problem with the abovementioned hadith, however, is identifying a source or reference for the addition. Providing an inadequate or incomplete reference is rather common in regard to hadith. Although several works citing this same hadith can be found, finding the original reference is problematic. ${ }^{8}$

It is not uncommon for academic researchers to come across a hadith that arouses their curiosity. Even if there is no reference, with "Complete Hadith Reference" (a searchable, comprehensive electronic collection) and other online resources, ${ }^{9}$ it has become possible to easily trace a hadith in its original Arabic text. However, a comprehensive search yielded no hadith with this "or a male over a female" part. It can easily be understood why this could provoke a researcher's curiosity further as to why all these works are citing a hadith that is not traceable.

As the author started to dig into this matter, several recent works were found citing the variant hadith, all of them secondary sources. For example, Amira Mashour (2017) ${ }^{10}$ and Shaheen Ali (2016) ${ }^{11}$ both referred to two earlier works by an eminent, contemporary female scholar: Azizah al-Hibri (1982). ${ }^{12}$ Upon finding the works of al-Hibri, the current author thought his search would end there. But, al-Hibri also does not refer to any original source. Instead, she cites Muhammad Abdul-Rauf (1977). ${ }^{13}$ Carl Grant (1995), ${ }^{14}$ H. Jawad (1998), ${ }^{15}$ Naheed Hasnat $(1998)^{16}$ and Aveling (2000) also cite Abdul Rauf. ${ }^{17}$

A search of Abdul-Rauf's work yielded detailed references to two early original hadith collections: Musnad Ahmad and Sunan al-Darimi ${ }^{18}$ But a dead-end was reached again as neither Musnad Ahmad nor Sunan al-Darimi contain any hadith with the part "or a male over a female." 19 In another book, Abdul-Rauf cites the same narration, but without the "or a male over a female" part. ${ }^{20}$

Another set of works citing this hadith refer to a different secondary text, written by Muhammad Abu-Nimer, a well-known scholar whose primary focus is on peace and conflict studies from an Islamic perspective. ${ }^{21}$ The works citing AbuNimer as a source for this hadith include: Julianne Hazen (2008), ${ }^{22}$ Brumberg and Shehata (2009), ${ }^{23}$ Amitabh Pal (2011), ${ }^{24}$ and Jeremy Sinseksy (2015). ${ }^{25}$ In AbuNimer (2000), the hadith is cited without any reference. However, in Abu-Nimer (2003) and Abu-Nimer (2006) a reference is given to Muhammad Ali (1941). ${ }^{26}$ The problem here is that Muhammad Ali (1941) does not report any hadith containing "male over a female". 
Of course, in quoting and citing hadith, an original hadith collection should be referred to; in these cases, we see that secondary sources were used without, it seems, actually confirming the text of the hadith. As part of this journey in due diligence, Abu-Nimer was contacted. In an email (dated October 24, 2017), he wrote: "I am still searching for the male female, but have not been able to find it. It seems that this not a reliable source. I must have read it somewhere but did not list the source. I would not rely on it anymore.'

This leaves us with another secondary reference, Dallmayr (1999), ${ }^{27}$ who cites Mohammed el-Awa (1980). ${ }^{28}$ But, in fact, el-Awa cites the relevant part of the last sermon of the Prophet without the part "a male over a female". El-Awa refers to a number of sources, including Imam Ibn Taymiyyah, but all those sources cite the relevant narration without the accretion "a male over a female". ${ }^{29}$

In some other works, original hadith collections are referred to. Donna Bowen (2004) mentions Musnad Ahmad, but without a full reference. ${ }^{30}$ Muslimvibe (undated) cites Musnad Ahmad with a specific reference. ${ }^{31}$ As mentioned already, Abdul-Rauf also cited Musnad Ahmad (with detailed reference) and al-Darimi (without detailed reference). The basic problem with all these references to the original hadith collections, however, is that there is no hadith in any of them with the part "or a male over a female".

A further search turned up another source, Imad-ad-Dean Ahmad (2011). ${ }^{32}$ Unfortunately, a similar dead-end was reached; Ahmad refers to a secondary source, Speight (1989), ${ }^{33}$ which in turn references just one word: "Hadith".

Table 1 provides these sources in chronological order.

\section{The Problem of Lack of Due Diligence}

First, there is a widespread practice among many Muslim scholars to cite hadith without any reference. For them, just mentioning al-Bukhari or al-Nasa' $i$ or alTirmidhi is enough. ${ }^{34}$ Second, there are those who do not feel the need to consult the original sources, being satisfied instead with secondary sources. Third, those who are content or comfortable with referring to secondary sources often do not have the due diligence to verify whether what the secondary sources cites actually exists in the original sources.

So, what may have happened in this case? The likely scenario is that one of the authors (the earliest we can identify is Muhammad Abdul-Rauf, 1977) cited the well-known hadith about Islam's egalitarianism, and the part "a male over a female" was an inadvertent accretion. There is no reason to believe that this was due to any deliberate insertion. However, that the references provided do not corroborate the narration indicates that the author was not meticulous. 
This then became a chain-error; without due diligence, later authors simply copied Abdul-Rauf as a secondary reference. Had they checked or verified the source and the exact text, especially with the original hadith collections, such as Musnad Ahmad or Sunan al-Darimi, this would not have occurred. To compound the error further, other Muslim scholars and academics have since used these secondary sources to quote this particular hadith with its accretion.

Apart from the fact that there was a lack of due diligence when it came to verifying the actual text of the hadith using original hadith collections, one other aspect is relevant. It is possible that the challenges and pressures of modern or contemporary issues related to gender facilitated the creation of a scholarly position that rendered such an accretion desirable - in other words, that scholars gradually started to read the sources through a lens of their own evolved position. Thus, one often comes across many contemporary works in which authors articulate a position that Islam upholds gender equality. For example:

Qur'an does not discriminate against women despite the sad and bitter fact of history that cumulative (Jewish, Christian, Hellenistic, Bedouin, and other) biases which existed in the Arab-Islamic culture of the early centuries of Islam infiltrated the Islamic tradition, largely through the hadith literature, and undermined the intent of the Qur'an to liberate women from the status of chattel or inferior creatures, making them free and equal to men. Not only does the Qur'an emphasise that righteousness is identical in the case of man or woman, but it affirms, clearly and consistently, women's equality with men and their fundamental right to actualise the human potential that they share equally with men $(16: 97,23: 35){ }^{35}$

Had we looked at the history of the world's religions from the past to the present, we would have found that Islam is the only religion that does not discriminate between [peoples] on the basis of color, gender, and other nationalities. ${ }^{36}$

Contemporary works on gender are full of such affirmations and articulations of Islam's belief in and upholding of gender equality. In post-revolutionary Iran, Ayatullah Saanei, a prodigy of the late Ayatullah Khomeini, made a powerful statement:

Quran equates between men and women and gives everyone equal rights. Color, ethnicity, nationality and religion are not standards 
that can be used to discriminate between people when it comes to their rights. For example, regarding the rights of non-Muslims, when the Quran refers to disbelievers, it does not mean those who follow a different religion than Islam... Non-Muslims around the world are not infidels. Christians, Marxists, Jews, and Zoroastrians are all nonMuslims but they are not disbelievers. Unfortunately, the majority of Muslim clerics and scholars do not differentiate between disbelievers and non-Muslims, which is the root of many problems. This is a very important matter that must be discussed in a conference between Shia and Sunni (theologians). All people are equal in their rights. Personally and from my perspective of Islam, I respect all mankind and the Quran respects all mankind not only Muslims. ${ }^{37}$

This is a rather bold and categorical statement from the Islamic perspective. Proceeding from this perspective,

...in the late 1990s, Saanei issued a series of bold fatwas forbidding discrimination based on race, gender, or ethnicity...He added: "How can we say Islam is a religion of justice if its laws consider women and non-Muslims unequal to Muslim men? Indeed, a man and woman are both humans, and Islam considers all humans of an equal value." ${ }^{38}$

Unfort unately, while such trail-blazing and illuminating statements have had an impact, for Muslims the validity and legitimacy of anything Islamic does not emanate from Islamic scholars and leaders. Rather, Muslims must be able to validate such opinions through the Qur'an and hadith. Unfortunately, the last sermon of the Prophet, although dealing with equality between groups, does not include a reference to sex or gender. There are many contemporary Muslims who might feel that this is disappointing. Perhaps a desire to see such a statement included in that proclamation was projected by someone's hand, inadvertently. Since, however, we do not know the intent behind whoever contributed the specific accretion under discussion here, we should not speculate. But, even if motivated by good intent, it was both unnecessary and unacceptable.

\section{The Problem of Weak (Daif) Hadith and Fabrications}

After the Qur'an, hadith are the second most important primary source in Islam. The life of the Prophet constitutes the principle example for Muslims to follow, and hadith remains the source for detail regarding this guidance and 
the message of the Qur'an. However, just as it is regarded as indispensable, it is also an Achilles heel. Unlike the Qur'an, which is Divine revelation, hadith requires authentication. Hadith collections consist of what hadith scholars have attempted to classify into authentic (sahih), weak (daif) and fabricated (maudu).

Authentic hadith constitute only a small percentage of all reported hadith. Religious scholars in general, and those associated with the field of law $(f i q h)$ in particular, have been constrained by the limited number of authentic hadith. For this reason, it has been common practice to resort to weak hadith when deducing rulings (ahkam). For reasons of embellishing or exaggerating the positive or negative import ance of something, adducing weak hadith has been made broadly permissible. ${ }^{39}$ A weak hadith is essentially, however, an unauthentic hadith and resorting to this genre of hadith has weakened Islam and its claim to truth.

The problem that is particularly relevant to this paper is the fabricated category of hadith. Fabricated hadiths consist of outright false attributions to the Prophet, as well as mixing an otherwise authentic hadith with an accretion, as here. Books of Qur'anic exegesis (tafsir), biographies (sirah), history (tarikh), or mysticism (tasawuf) are full of unauthentic and thus unreliable hadith. ${ }^{40}$ Modern hadith critiques highlight and expose the enormity of the problem and make the case for freeing Islam of not just fabricated hadith, but also weak hadith.

Muslims need to clarify to the rest of the world that Islam is indeed egalitarian in its own way, even in regard to gender. Quite justifiably, Muslims can project such egalitarianism based on the message of the Qur'an and the practical experience of the life and legacy of the Prophet Muhammad. This should not be and must not be done through accretions, about which the Prophet warned his followers sternly. As the Qur' an affirms, the essential criteria of merit is taqwa (God-consciousness), which is blind to gender.

The declaration of the Qur'an is adequate to demolish any notion of genderbased superiority; anything that contradicts this fundamental egalitarianism should be shunned by Muslims. ${ }^{41}$

\section{Conclusion}

This journey in due diligence began with an effort to verify a hadith cited by others. It is important to verify the original text (matn) of a hadith, which this author did as part of a research project, in case the hadith in question, although attributed to the Prophet, is not traceable.

While hadith scholars have dedicated their lives to collecting, recording, narrating, analysing and grading hadith, there are still serious problems and confusion. ${ }^{42}$ The Prophet has given a stern warning: "Whoever tells lies about 
me deliberately, let him find his place in Hell." ${ }^{33}$ While Muslims are generally careful that they do not deliberately attribute something falsely to the Prophet, sometimes lack of due diligence can create scenarios like the one examined here, where versions of a famous hadith enter circulation that contain parts not traceable to any earlier source. In modern times, more and more digital resources are available for easy and quick searches. By verifying hadith using original sources, researchers can avoid citing narrations or reports that do not exist. Notably, here we are not dealing with authenticating a hadith, but with grading it as sahih (authentic), daif (weak) or maudu ' (fabricated), which is the next level of due diligence.

The paper ends with the following actionable policy recommendations:

1. Scholars and researchers should check the original collections of hadith to verify a text and its source;

2. Referring to secondary sources when citing hadith should be avoided;

3. Digital resources that provide comprehensive databases/archives of Islamic materials, including hadith, such as Complete Islamic Reference (http://digital-fut ure.ca/en/product/al-marjaa-alakbar-in-the-islamicheritage-version-4-0/), should be used for verification purposes.

Table 1: Chronological listing of citations to the hadith containing the segment "a male over a female"

(full citation of each work is given in the footnotes)

1. 1977: M. Abdul Rauf, The Islamic View of Women and the Family, 13, citing Ahmad Ibn Hanbal, al-Musnad, 1930, 6, 411; Al-Darimi, alMusnad, none of which have the segment "a male over a female".

2. 1982: Azizah al-Hibri, 'A Study of Islamic Herstory,' citing M. Abdul Rauf, 1977, 21, where the latter does not have an appropriate reference.

3. 1982: Azizah al-Hibri, Women and Islam, citing Abdul-Rauf, 1977, 21, where the latter does not have an appropriate reference.

4. 1984: Muhammad Abdul-Rauf, A Muslim's View of Democratic Capitalism (American Enterprise Institute, 1984), 17, 64, where "male over a female" is missing. 
5. 1989: R. Marston Speight, God is One: The Way of Islam (Friendship Press, 1989), 50. This source includes the part "a male over a female". However, the author's reference is merely "(Hadith)".

6. 1994: Project on Religion and Human Rights (no reference).

7. 1995: Ruqaiyyah Waris Maqsood, Islam (no reference).

8. 1995: Carl Grant, EducaOxting for Diversity, citing M. Abdul Rauf, 1977, where the latter does not have an appropriate reference.

9. 1998: H. Jawad, The Rights of Women in Islam, citing M. Abdul Rauf, 1977, 21, where the latter does not have an appropriate reference.

10. 1998: Naheed Hasnat, 'Being 'Amreekan', citing M. Abdul Rauf, 1977, where the latter does not have any appropriate reference.

11. 1999: Fred Dallmayr, Border Crossings, citing Mohammed El-Awa, 1980, 111, where el-Awa does not contain the accretion.

12. 1999: Dahlia Eissa, 'Constructing the Notion of Male Superiority over Women in Islam' (no reference).

13. 13. 2000: Harry Aveling, Islam, Power citing M. Abdul Rauf, 1977, where the latter does not have an appropriate reference.

14. 2002: M. Abu Nimer (no reference).

15. 2003: M. Abu-Nimer, Nonviolence and Peacebuilding in Islam, citing M. Ali, 1941, where the latter does not have any hadith with "a male over a female".

16. 2003: Mir Zohair Husain, Global Islamic Politics (no reference) 
17. 2004. Donna Lee Bowen, 'Islamic Law and the Position of Women,' citing Ahmad Ibn Hanbal without reference. Musnad Ahmad does not contain the accretion.

18. 2006: Muhammad Abu-Nimer, 'A Framework for Nonviolence and Peacebuilding in Islam', citing M. Ali, 1941, where the latter does not have any hadith with "a male over female".

19. 2008: Julianne Marie Hazen, 'Contemporary Bosnian Sufism: Bridging The East and West,' M. A. Thesis. https://www.academia.edu/1056220/ Contemporary_Bosnian_Sufism._MA_Thesis, citing Muhammad Abu Nimer, 2006. The latter cites M. Ali, which is without any hadith with the "male over a female" segment.

20. 2009: Daniel Brumberg and Dina Shehata (2009), Conflict, Identity and Reform in the Muslim World: Challenges for U.S. Engagement, citing M. Ali, 1941, but the accretion is not traceable to Ali.

21. 2011: Ahmad, Imad-ad-Dean 'Muhammad on the US Constitution,' in Commentary on the Constitution from Plato to Rousseau, ed. Joshua Stein (Lanham, MD: Lexington Books, 2011), 50. He cites Ahmad's Musnad and Ibn Taymiyyah, where these sources do not contain the accretion.

22. 2011: Amitabh Pal, “'Islam'Means Peace,” citing Abu-Nimer, Nonviolence and Peace Building in Islam, where the latter cites Ali (1941), which does not contain any hadith with "a male over a female".

23. 2014: K. M. Baharul Islam, Issues in Women's Rights, citing M. Abdul Rauf, 1977, where the latter cites Ali (1941), which does not have any hadith with "a male over a female".

24. 2015: Jeremy Sinensky, 'Unlocking a Narrative', citing Abu-Nimer, 2003, where the latter cites Ali (1941), which does not have any hadith with "a male over a female". 
25. 2015: https://blessingsoflight.wordpress.com/2015/05/15/as-the-teethof-a-comb/ (no reference)

26. 2016: 'Status of women in Islam', citing https://www.al-islam.org/ message-thaqalayn/vol-11-no-1-spring-2010/stat us-women-islamcritical-analysis-matter-equality/statusf_4e3ca6cb_5, which cites Musnad Ahmad, 6:411, but the latter does not have the segment "a male over a female".

27. 2016: Gail Ukockis, Women's Issues for a New Generation, citing 'Women in Muslim Countries', which in turn cites Amjad Tariq, angelfire, without any reference to the hadith.

28. 2016: Samia Ullah, 'Veiling The Truth' (no reference).

29. 2016: Shaheen Sardar Ali, Modern Challenges to Islamic Law, citing alHibri, where the latter cites Abdul Rauf (1977), which is without any traceable reference.

30. 2017: Amira Mashhour, 'Islamic Law and Gender Equality', citing alHibri, where the latter does not have an appropriate reference.

31. Undated: Dr. Muhammad Amjad Tariq, 'Rights of Women under Islam' http://www.angelfire.com/mo/MWSA/rights.html (no reference)

\section{Notes}

* Mohammd Omar Farooq, University of Bahrain. Email: Farooqm59@yahoo. com.

1. Islamic law is more appropriately equated with fiqh than shariah. See Mohammad Omar Farooq and Nedal El Ghattis, 'In Search of the Shari'ah,' Arab Law Quarterly 32, no. 4 (2018): 315-54.

2. These six collections include Sahih al-Bukhari, Sahih Muslim, Sunan Abu Dawud, Jami al-Tirmidhi, Sunan al-Nasai' and Sunan Ibn Majah. For details see Jonathan Brown, The Canonization of al-Bukhari and Muslim: The Formation and Function of the Sunni Hadith Canon (Leiden: Koninklijke Brill, 2007); Mohammad Omar Farooq, Toward Our Reformation: From Legalism to ValueOriented Islamic Law and Jurisprudence (Herndon: IIIT, 2011); Wael Hallaq, 
'The Authenticity of Prophetic Hadith: A Pseudo-Problem,' Studia Islamica 99 (1999): 75-90.

3. Muhammad Mustafa Azami, Studies in Hadith Methodology and Literature (Kuala Lumpur: Islamic Book Trust, 2002); Mohammad Hashim Kamali, A Textbook of Hadith Studies: Authenticity, Compilation, Classification and Criticism of Hadith (Leicester: Islamic Foundation, 2014).

4. Mohammad Omar Farooq, 'The Farewell Sermon of the Prophet: An Analytical Review,' Islam and Civilizational Review 9, no. 3 (2015): 322-42.

5. Musnad Ahmad, \#23105, Complete Islamic Reference, a comprehensive database of Arabic/Islamic sources. Available at: http://digital-future.ca/en/ product/al-marjaa-alakbar-in-the-islamic-heritage-version-4-0/.

6. Israr Ahmad Khan, Authentication of Hadith: Redefining the Criteria (London: International Institute of Islamic Thought, 2010); Jonathan Brown, Hadith: Muhammad's Legacy in the Medieval and Modern World (Oxford: Oneworld Publication, 2009).

7. Dahlia Eissa Constructing the Notion of Male Superiority over Women in Islam, WLUML Occasional Paper No. 11 (1999). Available at: http://www.wluml. org/sites/wluml.org/files/import/english/pubs/pdf/ occpaper/OCP-11.pdf. [No reference].

8. Ruqaiyyah Waris Maqsood, Islam (Oxford: Heinemann Educational, 1995), 105; Project on Religion and Human Rights, Religion and Human Rights (1994), 85; Mir Zohair Husain, Global Islamic Politics, $2^{\text {nd }}$ ed. (New York: Longman, 2003), 24; Blog (undated); 'Blessings of Light'. Available at: https:// blessingsoflight.wordpress.com/2015/05/15/as-the-teeth-of-a-comb/; Samia Ullah, 'Veiling The Truth: Women's Rights Under Islam,' (2016). Available at: https://www.theodysseyonline.com/veiling-truth-womens-rights-under-islam; Mrs. Muhammad Amjad Tariq (undated), 'Rights of Women under Islam'. Available at: http://www.angelfire.com/mo/MWSA/rights.html; Gail Ukockis, Women's Issues for a New Generation: A Social Work Perspective (Oxford: Oxford University Press, 2016). Ukockis does provide a secondary reference (Muhammad Amjad Tariq), listed here among those works that did not provide any reference to the hadith.

9. Al-Marja'a al-Akbar in the Islamic Heritage, Version 4, Digital Future, n.d., http://www.digital-future.ca/en/product/al-marjaa-alakbar-in-the-islamicheritage-version-4-0. (Accessed on: 15 October 2018). The hadith literature has also been checked using the online Arabic resource, Al-Shamela, http://shamela. ws/.

10. Amira Mashhour, 'Islamic Law and Gender Equality,' Human Rights Quarterly 27 (2005), 562-96 in Mashood Baderin (ed), Islamic Law in Practice, 3, citing Azizah al-Hibri, 'A Study of Islamic Herstory: Or How Did We Ever Get Into this Mess?’ Women's Studies International Forum 5. no. 2 (1982), 218.

11. Shaheen Sardar Ali, Modern Challenges to Islamic Law (Cambridge: Cambridge University Press, 2016), 33 citing al-Hibri.

12. Azizah al-Hibri, 'A Study of Islamic Herstory?' 207-19; Azizah al-Hibri, Women and Islam, (Oxford: Pergamon Press, 1982), 218, citing Abdul-Rauf, 1977, 21.

13. M. Abdul Rauf, The Islamic View of Women and the Family (New York: Robert Speller and Sons, 1977), 13, citing Ahmad Ibn Hanbal, al-Musnad, 1930, Vol. 
6, 411; Al-Darimi, al-Musnad. Abdul-Rauf was a noted scholar who served as Rector of the International Islamic University of Malaysia and Imam of the Islamic Centre in Washington DC.

14. Carl Grant, Educating for Diversity: An Anthology of Multicultural Voices (Boston: Allyn and Bacon, 1995), 175, citing Abdul Rauf, Islamic View of Women.

15. Haifaa Jawad, The Rights of Women in Islam: An Authentic Approach (New York: St. Martin's Press, 1998), 5, citing Abdul Rauf, Islamic View of Women, 21.

16. Naheed Hasnat, 'Being “Amreekan”: Fried Chicken versus Chicken Tikka,' in A Patchwork Shawl: Chronicles of South Asian Women in America, ed. Shamita Das Dasgupta (New Brunswick: Rutgers University Press, 1998), 33-45, 40, citing Abdul Rauf, Islamic View of Women.

17. Harry Aveling, Islam, Power and Gender (Bangi: Penerbit University Kebangsaan Malaysia, 2000), 211, citing Abdul Rauf, Islamic View of Women.

18. Ibid.

19. Musnad Ahmad includes this hadith once, Vol. 6, \#23105, without the specified part. Sunan al-Darimi includes no hadith pertaining to this topic at all.

20. Muhammad Abdul Rauf, A Muslim's View of Democratic Capitalism (Washington: American Enterprise Institute, 1984), 17, \#64, citing 'Amr Ibn Bakr al-Jahiz, al-Bayan wa al-Tabyin (Cairo: Khanki Press, 1948), 2, 19. A classical literary author with immense influence, al-Jahiz died in 255/869. Abdul Rauf's work is available at: http://www.aei.org/wp-content/uploads/2014/06/-amuslims-reflections-on-democratic-capitalism_143730388752.pdf.

21. Muhammad Abu-Nimer, 'Framework for Nonviolence and Peacebuilding in Islam,' in Contemporary Islam: Dynamic, Not Static, ed. Abdul Aziz Said, Mohammed Abu-Nimer and Meena Sharify-Funk (New York: Routledge, 2006), 148, citing Muhammad Ali, A Manual of Hadith (Lahore: Ahmadiya Anjuman, 1941); M. Abu Nimer, 'Values of Peacebuilding and Nonviolence in Islam: Ideals and Reality, The American Muslim (2002), http://theamericanmuslim. org/tam.php/features/articles/values_of_peacebuilding_and_nonviolence_in islam_ideals_and_reality/; M. Abu-Nimer, Nonviolence and Peacebuilding in Islam: Theory and Practice (Gainesville: University of Florida Press, 2003), 58.

22. Julianne Marie Hazen, 'Contemporary Bosnian Sufism: Bridging the East and West,' M. A. Thesis (2008), https://www.academia.edu/1056220/ Contemporary_Bosnian_Sufism._MA_Thesis, citing Abu Nimer, 'Nonviolence and Peacebuilding in Islam'.

23. Daniel Brumberg and Dina Shehata, Conflict, Identity and Reform in the Muslim World: Challenges for U.S. Engagement (Washington: US Institute of Peace Press, 2009), 133.

24. Amitabh Pal, 'Islam' Means Peace: Understanding the Muslim Principle of Nonviolence Today (Santa Barbara, CA: ABC-CLIO, 2011), citing Abu-Nimer, 'Nonviolence and Peace Building in Islam', 61.

25. Jeremy Sinensky, 'Unlocking a Narrative: Stories of Islam and Peacebuilding and Conflict Transformation,' Capstone Collection. Paper 2764, 2015, cites Abu-Nimer, 2003, 58.

26. Muhammad Ali, A Manual of Hadith. 
27. Fred Dallmayr, Border Crossings: Toward a Comparative Political Theory (Lanham: Lexington Books, 1999), 83 citing Mohammed el-Awa, On the Political System of the Islamic State (Chicago: American Trust Publications, 1980), 111.

28. Ibid., 111.

29. El-Awa's footnote \#2 on that page states: "Reported by Imam Ahmed in $\mathrm{Al}$ Musnad and as quoted by Ibn Taymiyya in Iqtidha al-Sirat al-Mustaqim, 144." Also referred to is the complete text of the address in al-Watha'iq al-Siyasiyah by Muhammad Hamid Allah.

30. Donna Lee Bowen, 'Islamic Law and the Position of Women', in Islam and Social Policy, ed. Stephen P. Heyneman (Nashville: Vanderbilt University Press, 2004), 14-44, says: "Hadith from Ahmad Ibn Hanbal."

31. 'Status of Women in Islam: A critical analysis on the matter of equality,' https:// themuslimvibe.com/muslim-lifestyle-matters/women/status-of-women-inislam-a-critical-analysis-on-a-matter-of-equality, citing https://www.al-islam. org/message-thaqalayn/vol-11-no-1-spring-2010/status-women-islam-criticalanalysis-matter-equality/status\#f_4e3ca6cb_5, which cites Musnad Ahmad, 6:411, but the latter does not have any hadith with "a male over a female".

32. Imad-ad-Dean Ahmad, 'Muhammad on the US Constitution,' in Commentary on the Constitution from Plato to Rousseau, ed. Joshua Stein (Lanham: Lexington Books, 2011), 70-82.

33. R. Marston Speight, God is One: The Way of Islam (New York: Friendship Press, 1989), 50.

34. As prominent as contemporary scholar Shaikh Yusuf al-Qaradawi is, he has also been negligent in this regard. See for example, "Reported by al-Tirmidhi and Ibn Majah": Yusuf Al-Qaradawi, The Lawful and the Prohibited in Islam (Kuala Lumpur: Islamic Book Trust, 2013), 5; "Related by Al-Bukhari and Muslim": Salih al-Fawzan, Concise Commentary on the Book of Tawhid (Riyadh: AlMaiman Publishing House, 2005), 14; "Al-Bukhari transmitted ...": AbdulHamid Kishk, The World of the Angels (London: Dar al-Taqwa, 1994), 20, https://kalamullah.com/Books/The\%20World\%20of\%20The\%20Angels. pdf; "Reported by Bukhari”: Sayyid Qutb (2006). Milestones (Birmingham: Maktabah), 175, \#149.

35. V.A. Mohamd Ashrof, Islam and Gender Justice: Questions at the Interface (Delhi: Kalpaz Publications, 2005), 80-1.

36. Najebah Marafi, The Intertwined Conflict: The Difference Between Culture and Religion (London: Xlibris Publishing, 2012), 36.

37. Yousef Saanei, 'The Women's Mufti: Interview with Grand Ayatollah Yousef Saanei,' Asharq Al-Awsat (English ed.), April 6, 2007, https://eng-archive. aawsat.com/theaawsat/features/the-womens-mufti-interview-with-grandayatollah-yousef-saanei.

38. Nader Hashemi, Islam, Secularism and Liberal Democracy: Toward a Democratic Theory for Muslim Societies (Oxford: Oxford University Press, 2009), 93 citing Robin Wright, Sacred Rage: The Wrath of Militant Islam (New York: Touchstone Books, 2001), 28.

39. Jonathan Brown, 'Even if it's not true it's true: Using Unreliable Hadiths in Sunni Islam,' Islamic Law and Society 18 (2011), 1-52. 
40. Yousuf al-Qaradawi, Comprehensive and Controversy: Approaching the Sunnah (Herndon, Virginia: International Insitute of Islamic Thought, 2007); Azami, Hadith Methodology and Literature; Israr Ahmad Khan, Authentication of Hadith: Redefining the Criteria (Herndon, Virginia: International Institute of Islamic Thought, 2010); Kamali, Textbook of Hadith Studies.

41. Jamal Badawi, Gender Equity in Islam: Basic Principles (Plainfield: American Trust Publications, 1995), 11-3; Asma Barlas, Believing Women in Islam: Unreading Patriarchal Interpretations of the Qur'an (Austin: University of Texas Press, 2019), 108; Amina Wadud, Inside the Gender Jihad: Women's Reform in Islam (London: Oneworld, 2006); Zahra Ayubi, Gendered Morality: Classical Islamic Ethics of the Self, Family and Society (New York: Columbia University Press, 2019); Ahmed Affi and Hassa Affi, Contemporary Interpretation of Islamic Law (Leicester: Matador, 2014), 73.

42. Farooq, Toward Our Reformation. See the chapter on 'Islamic Law and the Use and Abuse of Hadith'; Muhammad Zubayr Siddiqi, Hadith Literature: Its Origin, Development, Special Features (Cambridge: Islamic Texts Society, 1961).

43. Sunan Ibn Majah, Book of Sunnah, https://sunnah.com/urn/1250330. 